\title{
Motivos del Juan Cristóbal
}

\section{MOMENTO}

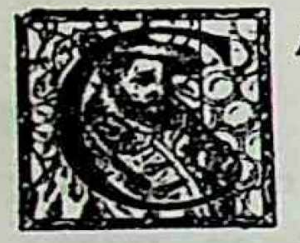

AE la tarde. Está callado el piano.

Ronda el alma celeste de Antonieta Jeanin.

Están juntas las almas y están juntas las manos de Juan Cristóbal Kraft y de Olivier.

El hilito de lágrimas de una canción lejana se desteje en las manos de la gris tarde quieta.

Llega la oscuridad a toque de campanas... y silenciosamente el alma de Antonieta.

Brota de toda cosa cual dolorosa yema de floración nostálgica ultraterrena, y va nevando este mundo con la quietud suprema de una losa del cementerio de Ivry. 